\title{
The Impact of COVID-19 on Pregnancy and Emerging Therapeutic Drug Development Options
}

\author{
Allyah Abbas-Hanif ${ }^{1}$, Homira Rezai ${ }^{1}$, and Asif Ahmed ${ }^{2}$ \\ ${ }^{1}$ Mirzyme Therapeutics \\ ${ }^{2}$ MirZyme Therapeutics
}

February 12, 2021

\begin{abstract}
Emerging data shows pregnant women with COVID-19 are at significantly higher risk of severe outcomes compared to nonpregnant women of similar age. This review discusses the invaluable insight revealed from vaccine clinical trials in women who were vaccinated and inadvertently became pregnant during the trial period. It further explores a number of clinical avenues in their management and proposes a drug development strategy in-line with clinical trials for vaccines and drug treatments for the drug development community. Little is known of the long-term effects of COVID-19 on the mother and the baby. We provide a rationale for our hypothesis that COVID-19 predisposes pregnant women to cardiovascular diseases later in life, in a similar way, to preeclampsia and may increase the risk of preeclampsia in their subsequent pregnancy. This is an ever-evolving landscape and early knowledge for healthcare providers and drug innovators is offered to ensure benefits outweigh the risks.
\end{abstract}

\section{Hosted file}

BJP_COVID-19_Pregnancy_Drug_Vaccine__Review.pdf available at https://authorea.com/users/ 395334/articles/508633-the-impact-of-covid-19-on-pregnancy-and-emerging-therapeuticdrug-development-options

\section{Hosted file}

Table 1_Covid_BJP_Review.pdf available at https://authorea.com/users/395334/articles/508633the-impact-of-covid-19-on-pregnancy-and-emerging-therapeutic-drug-development-options

\section{Hosted file}

Figure 1_COVID_BJP_Pregnancy_Plan.pptx available at https://authorea.com/users/395334/ articles/508633-the-impact-of-covid-19-on-pregnancy-and-emerging-therapeutic-drugdevelopment-options

\section{Hosted file}

Figure 2_Covid_BJP_Review.pptx available at https://authorea.com/users/395334/articles/ 508633-the-impact-of-covid-19-on-pregnancy-and-emerging-therapeutic-drug-developmentoptions 